\title{
Relationship between ghrelin and obestatin levels and ghrelin/obestatin ratio in patients with asthma
}

\author{
Deniz KIZILIRMAK ${ }^{\mathbf{1}}$ (ID) \\ Bülent BOZKURT ${ }^{2}($ ID) \\ Harun KARAMANLI ${ }^{3}$ (ID)
}

${ }^{1}$ Department of Chest Diseases, Faculty of Medicine, Celal Bayar University, Manisa, Turkey

${ }^{1}$ Celal Bayar Üniversitesi Tıp Fakültesi, Gögüs Hastalıkları Anabilim Dalı, Manisa, Türkiye

${ }^{2}$ Clinic of Allergic Diseases, Lokman Hekim Hospital, Ankara, Turkey

${ }^{2}$ Lokman Hekim Hastanesi, Allerjik Hastalıklar Kliniği, Ankara, Türkiye

${ }^{3}$ Clinic of Chest Diseases, Atatürk Training and Research Hospital, Ankara, Turkey

3 Ankara Atatürk Eğitim ve Araştırma Hastanesi, Göğüs Hastalıkları Kliniği, Ankara, Türkiye
Cite this article as: KIzllırmak D, Bozkurt B, Karamanlı $H$. Relationship between ghrelin and obestatin levels and ghrelin/obestatin ratio in patients with asthma. Tuberk Toraks 2020;68(1):9-16.

\section{Yazışma Adresi (Address for Correspondence)}

\section{Dr. Deniz KIZILIRMAK}

Celal Bayar Üniversitesi Tıp Fakültesi, Gögüs Hastalıkları Anabilim Dalı, MANISA - TÜRKIYE

e-mail: dr_dkizilirmak@yahoo.com

CCopyright 2020 by Tuberculosis and Thorax.

Available on-line at www.tuberktoraks.org.com

\begin{abstract}
Relationship between ghrelin and obestatin levels and ghrelin/obestatin ratio in patients with asthma

Introduction: This study aimed to evaluate serum levels of ghrelin and obestatin as well as the ghrelin/obestatin ratio in non-obese patients with asthma and in healthy non-asthmatic controls and analyzed the relationships to clinical outcomes.
\end{abstract}

Materials and Methods: 51 patients with stable persistent asthma and 36 healthy controls were included to the study. Pulmonary function tests were conducted in all case. Skin prick test and an asthma control test were conducted in patients with asthma. All patients and controls were compared in terms of ghrelin and obestatin levels, as well as the ghrelin/obestatin ratio. Plasma concentrations of ghrelin and obestatin were detected by enzymelinked immunosorbent assay. Homeostasis model assessment-insulin resistance (HOMA-IR) scores were calculated as an index of insulin resistance.

Results: No differences in ghrelin or obestatin levels or the ghrelin/obestatin ratio were detected between patients with asthma and the control group. Ghrelin levels were significantly lower in obese patients. The HOMA-IR score was significantly higher in patients with asthma than in controls.

Conclusion: Ghrelin and obestatin levels, and the ghrelin/obestatin ratio, were similar in controls and patients with stable asthma. Although the groups were similar in terms of body mass index and waist circumference, the HOMA-IR score was significantly higher in patients with asthma.

Key words: Asthma; ghrelin; obestatin; insulin resistance 


\title{
Öz
}

\section{Serum ghrelin, obestatin düzeyleri ve ghrelin/obestatin oranının astım ile ilişkisi}

Giriş: Obezite astım için bağımsız bir risk faktörüdür. Obezite ilişkili hormonların astım gelişiminde önemli rol oynadığı düşünülmektedir. Bu çalışmada ghrelin, obestatin düzeyleri ve ghrelin/obestatin hormonunun astımlı hastalar ve sağ/ıkı kontrol grubu arasındaki ilişkileri ve klinik sonuçlarını araştırmak amaçlanmıştır.

\begin{abstract}
Materyal ve Metod: Elli bir stabil dönemde, persistan astımlı hasta ve 36 sağlıklı kontrol grubu çalışmaya dahil edildi. Tüm olgulara solunum fonksiyon testi yapıldı. Astımlı hastalara astım kontrol testi uygulandı. Allerjik ve allerjik olmayan astımlı hastalar arasındaki farklılığı araştırma amacıyla astımlı hastalara deri prik testi uygulandı. Tüm hastalar ve kontrol grubu ghrelin, obestatin düzeyleri ve ghrelin/obestatin oranı açısından araştııldı. Ghrelin ve obestatinin plazma konsantrasyonları enzim bağlı immünosorbent tetkiki ile tespit edildi. Homeostaz modeli değerlendirme-insülin direnci (HOMA-IR) skorları, insülin direncinin bir indeksi olarak hesaplandı. Tüm olgularda C-reaktif protein seviyeleri ölçüldü.
\end{abstract}

Bulgular: Astımlı hastalar ve kontrol grubu arasında ghrelin veya obestatin düzeyleri veya ghrelin/obestatin oranları açısından anlamIı bir fark bulunmadı. Ghrelin düzeyleri obez hastalarda anlamlı derecede düşüktü. HOMA-IR skoru astım grubunda kontrol grubuna göre anlamlı olarak yüksek bulundu.

Sonuç: Ghrelin, obestatin düzeyleri ve ghrelin/obestatin oranı kontroller ve stabil astımlı hastalarda benzerdi. Her ne kadar gruplar vücut kitle indeksi ve bel çevresi açısından benzer olsa da, HOMA-IR skoru astımlı hastalarda kontrollere göre anlamlı derecede yüksekti. Bu sonuçlara dayanarak astımda kronik inflamasyon, obeziteden bağımsız olarak insülin direncine neden olabilir.

Anahtar kelimeler: Astım; ghrelin; obestatin; insülin direnci

\section{INTRODUCTION}

Asthma is a chronic lung disease characterized by episodes of airway obstruction. Obesity has been established as an independent risk factor for asthma (1). The mechanisms underlying this relationship are not completely understood. Asthma is observed more frequently and asthma symptoms can be more difficult to control in obese patients (2). However, it is not well understood how obesity worsens asthma. Obesityrelated hormones are thought to play a role in asthma development (3). Both murine and human studies have demonstrated that the pro-inflammatory effects of ghrelin might be relevant to asthma (4).

Ghrelin is a 28 amino acid peptide hormone with a feeding drive stimulating effect that controls energy balance (5). The gene that encodes obestatin also encodes ghrelin (6). Ghrelin and obestatin have the same precursors; however, their physiological functions are quite opposite (6). The balance between obestatin and ghrelin plays a substantial role in the control of body weight and energy (6). Serum concentrations of ghrelin and body mass index (BMI) are negatively correlated in humans (7). However, the role of obestatin and ghrelin in asthma and their relationship with asthma remain unknown.

Two studies have reported that ghrelin levels are lower in patients with asthma compared to healthy controls. Unfortunately, no study has investigated the relationship between serum levels of obestatin and asthma. A few studies have been conducted on ghrelin in adults with asthma but no information is available about obestatin in these patients. This study evaluated levels of the energy metabolic-related hormones obestatin and ghrelin in non-obese patients with asthma and in healthy controls without asthma. We also investigated the association between these hormone levels and clinical outcomes, inflammation parameters, and the sex ratio.

\section{MATERIALS and METHODS}

In all, 51 patients with stable persistent asthma (age, 18-74 years) and 36 healthy controls were enrolled between September 2014 and January 2015. Exclusion criteria were chronic respiratory disease other than asthma; recent lower or upper respiratory tract infection; systemic inflammatory, endocrinological, or metabolic diseases; use of an antihistamine or nonsteroidal anti-inflammatory drug; having received hormonal replacement treatment; and a smoking history in combination with an asthma attack within the last 3 months. Patients who had known conditions that could affect plasma levels of obestatin and ghrelin, such as liver, gastrointestinal, thyroid, metabolic, kidney disease, or other lung diseases were excluded with biochemical tests and imaging methods $(8,9)$. Patients were consulted to Internal Medicine Department when suspicious results were observed.

This study was approved by local medical ethics committee (ethics approval number: 99950669/318). All subjects signed an informed consent form before taking part in this study. 
A pulmonary function test was conducted in all cases. Patients with asthma also receive a skin prick test and completed an asthma control test (ACT). The BMI of patients was calculated as weight $(\mathrm{kg}) /$ height $^{2}(\mathrm{~m})$. Fasting blood samples were drawn to measure serum levels of obestatin, ghrelin, insulin, C-reactive protein (CRP), total IgE levels and fasting blood glucose as well as to prepare a hemogram. All patients and controls were compared in terms of ghrelin and obestatin levels, as well as the ghrelin/obestatin ratio.

\section{Obestatin and Ghrelin Assays}

Fasting venous blood was obtained in $5 \mathrm{~mL}$ test tubes containing EDTA (Ethylenediaminetetraacetic acid) from the antecubital vein of all participants between 7:00 and 8:00 a.m. The blood samples were centrifuged for $30 \mathrm{~min}$ at $4^{\circ} \mathrm{C}$ and $2.200 \mathrm{rpm}$ for $10 \mathrm{~min}$. The plasma samples were stored at $-70^{\circ} \mathrm{C}$ until assay. Obestatin and ghrelin were detected with enzymelinked immunoassays (ELISAs) (Biotek ELISA microplate reader and ELX 800 ve ELISA microplate washer, Winooski, VT, USA). Obestatin and ghrelin were assayed with sandwich ELISA kits (SUNRED ELISA kit, cat. nos.: 201-12-0971 and 200-12-0973; Shanghai Sunred Biological Technology Co., Ltd., Shanghai, China). The minimum detectable concentration was $100 \mathrm{pg} / \mathrm{mL}$.

\section{Statistical Analysis}

Mean \pm standard deviation values were calculated for normally distributed data, and median values were determined for non-normally distributed data. Pearson's chi-square test was performed for categorical variables. Differences between the groups were analyzed using an unpaired Student's t-test. Correlations were performed using Pearson's bivariate correlation analysis. A p-value $<0.05$ was considered significant. Data were analyzed with SPSS ver. 10.0 for Windows software (SPSS Inc., Chicago, IL, USA).

Table 1. Demographics of the study groups

\begin{tabular}{|lccc|} 
& $\begin{array}{c}\text { Control group } \\
(\mathbf{n = 3 6 )}\end{array}$ & $\begin{array}{c}\text { Asthma group } \\
(\mathbf{n = 5 1 )}\end{array}$ & $\mathbf{p}$ \\
\hline Age (year) & $33.22 \pm 10.68$ & $38.94 \pm 14.86$ & 0.051 \\
Height $(\mathrm{cm})$ & $169.75 \pm 9.47$ & $162.16 \pm 10.36$ & $\mathbf{0 . 0 0 1 *}$ \\
Weight $(\mathrm{kg})$ & $71.97 \pm 16.53$ & $72.57 \pm 16.74$ & 0.87 \\
BMI $\left(\mathrm{kg} / \mathrm{m}^{2}\right)$ & $24.87 \pm 4.87$ & $27.80 \pm 6.94$ & 0.055 \\
Waist circumference $(\mathrm{cm})$ & $83.42 \pm 12.13$ & $87.47 \pm 15.54$ & 0.19 \\
\hline BMl: Bbody mass index. & & & \\
\hline
\end{tabular}

\section{RESULTS}

Patients with persistent asthma included 37 females and 14 males (mean age, $38.94 \pm 14.86$ years) and the controls included 20 females and 16 males (mean age, $33.22 \pm 10.68$ years; $p=0.051)$. The mean $\mathrm{BMI}$ was $27.80 \pm 6.94 \mathrm{~kg} / \mathrm{m}^{2}$ in patients with asthma and 24.87 $\pm 4.87 \mathrm{~kg} / \mathrm{m}^{2}$ in controls $(\mathrm{p}=0.055)$. Mean waist circumference was $87.47 \pm 15.54 \mathrm{~cm}$ in patients with asthma and $83.42 \pm 12.13 \mathrm{~cm}$ in controls $(p=0.19)$. Mean age, sex ratio, BMI, and waist circumference were similar between the groups (Table 1).

No differences in ghrelin or obestatin levels or the ghrelin/obestatin ratio were observed between patients with asthma and the control group. Mean ghrelin level was $2,319.89 \pm 2,082.79 \mathrm{pg} / \mathrm{mL}$ in patients with asthma and 2,275.35 $\pm 1,977.03 \mathrm{pg} / \mathrm{mL}$ in controls $(\mathrm{p}=$ 0.92). Mean obestatin level was $6.28 \pm 5.60 \mathrm{ng} / \mathrm{mL}$ in patients with asthma and $8.50 \pm 7.41 \mathrm{ng} / \mathrm{mL}$ in controls $(p=0.11)$. The ghrelin/obestatin ratio was 571.36 $\pm 1,122.50$ in patients with asthma and $347.86 \pm$ 174.38 in controls $(p=0.24)$.

All cases were compared to correlate ghrelin and obestatin levels, the ghrelin/obestatin ratio, and mean BMI. The bivariate correlation analysis did not reveal any association between plasma obestatin level and BMI ( $r=-0.181, p=0.093)$. A weak negative correlation was detected between ghrelin level and BMI $(r=$ -0.230, $p=0.032)$. No correlation was detected between the ghrelin/obestatin ratio and BMI ( $r=$ $-0.022, p=0.84$ ).

Systemic inflammation is a clinical characteristic of asthma (10). CRP levels were significantly higher in patients with asthma than in control group $(p=0.019)$. Plasma obestatin and CRP were positively correlated.

No correlation was detected between the ACT score and CRP levels in 51 patients with asthma $(r=-0.095$, $p=0.51$ ). No relationship was found between the ACT 
score in the full control, partial control, and the uncontrolled group in multivariate analyses $(p=0.10)$.

No relationship was detected between the ACT and HOMA-IR scores in the 51 patients with asthma ( $r=$ -0.136, $\mathrm{p}=0.34$ ). No relationship in the ACT scores was detected when patients with controlled, partially controlled, or uncontrolled asthma were examined in multivariate analyses $(p=0.42)$.

The HOMA-IR score was $3.58 \pm 2.68$ in patients with asthma and $1.94 \pm 1.07$ in controls. Despite the similar $\mathrm{BMI}$ and waist circumference between the two groups, the HOMA-IR score was significantly higher in patients with asthma than in controls $(p<0.001)$ (Table 2).

No difference in total IgE level was detected between patients with asthma and the control group $(p=0.29)$.

\section{Obesity Status}

In all, 62 non-obese and 25 obese patients were included according to the $\mathrm{WHO}$ criteria. The mean ghrelin level was $1.61 \pm 1.12 \mathrm{ng} / \mathrm{mL}$ in obese patients and $2.58 \pm 2.23 \mathrm{ng} / \mathrm{mL}$ in the non-obese group $(\mathrm{p}=$ 0.042). The mean obestatin level was $6.02 \pm 5.70 \mathrm{ng} /$ $\mathrm{mL}$ in obese patients, and $7.68 \pm 6.74 \mathrm{ng} / \mathrm{mL}$ in the non-obese group $(p=0.28)$. The ghrelin/obestatin ratio was $0.36 \pm 1.45$ in the obese group and $0.526 \pm 1.03$ in the non-obese group $(p=0.43)$. The mean ACT scores were $15.80 \pm 4.48$ in obese patients with asthma and $18.16 \pm 3.55$ in non-obese patients with asthma. Control of asthma was worse in the obese group than in the non-obese group $(p=0.042)$.

\section{Allergy Test Status}

In all, $32(62.7 \%)$ patients with asthma were not sensitive to aeroallergens in skin prick tests, whereas 19 $(37.3 \%)$ were sensitive. The mean age was $42.95 \pm$ 15.81 years in the allergy-positive group and $36.56 \pm$ 13.97 years in the allergy-negative group $(p=0.14)$. The mean BMIs and mean waist circumferences in these groups were $28.04 \pm 7.18 \mathrm{~kg} / \mathrm{m}^{2}$ and $90.00 \pm$ $17.33 \mathrm{~cm}$ and $27.66 \pm 6.91 \mathrm{~kg} / \mathrm{m}^{2}$ and $85.97 \pm 14.45$ $\mathrm{cm}$, respectively. Table 3 summarizes demographic variables according to allergy test responses.

Table 2. Biochemical and respiratory parameters in the groups

\begin{tabular}{|c|c|c|c|}
\hline & $\begin{array}{c}\text { Control group } \\
(n=36)\end{array}$ & $\begin{array}{l}\text { Asthma group } \\
\quad(n=51)\end{array}$ & $\mathbf{p}$ \\
\hline FVC & $93.67 \pm 9.39$ & $97.75 \pm 13.90$ & 0.13 \\
\hline $\mathrm{FEV}_{1}$ & $98.81 \pm 10.28$ & $98.65 \pm 16.25$ & 0.96 \\
\hline $\mathrm{FEV}_{1} / \mathrm{FVC}$ & $79.39 \pm 4.56$ & $78.29 \pm 4.53$ & 0.27 \\
\hline $\mathrm{FEF}_{25-75}$ & $93.50 \pm 23.11$ & $82.86 \pm 32.68$ & 0.097 \\
\hline Ghrelin (ng/mL) & $2.28 \pm 1.98$ & $2.33 \pm 2.08$ & 0.92 \\
\hline Obestatin (ng/mL) & $8.50 \pm 7.41$ & $6.28 \pm 5.60$ & 0.11 \\
\hline Ghrelin/obestatin & $0.35 \pm 1.74$ & $0.57 \pm 1.12$ & 0.24 \\
\hline Total IgE (IU/mL) & $134.98 \pm 300.77$ & $212.58 \pm 355.88$ & 0.29 \\
\hline $\mathrm{CRP}(\mathrm{mg} / \mathrm{L})$ & $1.65 \pm 1.99$ & $3.65 \pm 4.72$ & $0.019 *$ \\
\hline HOMA-IR & $1.94 \pm 1.07$ & $3.58 \pm 2.68$ & $<0.001 *$ \\
\hline
\end{tabular}

Table 3. Demographics in the allergic and non-allergic groups

\begin{tabular}{|lccc|} 
& $\begin{array}{c}\text { Allergic group } \\
(\mathbf{n = 3 6 )}\end{array}$ & $\begin{array}{c}\text { Non-allergic group } \\
(\mathbf{n = 5 1 )}\end{array}$ & $\mathbf{p}$ \\
\hline Age (year) & $36.56 \pm 13.97$ & $42.95 \pm 15.81$ & 0.14 \\
Height $(\mathrm{cm})$ & $164.34 \pm 10.29$ & $158.47 \pm 9.63$ & $\mathbf{0 . 0 4 9 *}$ \\
Weight $(\mathrm{kg})$ & $74.34 \pm 17.92$ & $69.58 \pm 14.50$ & 0.33 \\
BMI $\left(\mathrm{kg} / \mathrm{m}^{2}\right)$ & $27.66 \pm 6.91$ & $28.04 \pm 7.18$ & 0.85 \\
Waist circumference $(\mathrm{cm})$ & $85.97 \pm 14.45$ & $90.00 \pm 17.33$ & 0.38 \\
\hline
\end{tabular}


Table 4. Mean blood parameters in the allergic and non-allergic groups

\begin{tabular}{|c|c|c|c|}
\hline & $\begin{array}{l}\text { Non-allergic group } \\
\quad(n=32)\end{array}$ & $\begin{array}{l}\text { Allergic group } \\
\quad(n=19)\end{array}$ & $\mathbf{p}$ \\
\hline Ghrelin (ng/mL) & $2.11 \pm 1.76$ & $2.68 \pm 2.56$ & 0.35 \\
\hline Obestatin $(\mathrm{ng} / \mathrm{mL})$ & $6.08 \pm 5.23$ & $6.63 \pm 6.31$ & 0.74 \\
\hline Ghrelin/obestatin & $0.41 \pm 1.74$ & $0.85 \pm 1.82$ & 0.18 \\
\hline Total IgE (IU/mL) & $171.65 \pm 230.55$ & $281.51 \pm 502.26$ & 0.29 \\
\hline $\mathrm{CRP}(\mathrm{mg} / \mathrm{L})$ & $3.72 \pm 5.32$ & $3.52 \pm 3.62$ & 0.88 \\
\hline HOMA IR & $3.96 \pm 3.10$ & $2.93 \pm 1.65$ & 0.19 \\
\hline ACT & $18.00 \pm 4.16$ & $15.95 \pm 3.66$ & 0.081 \\
\hline
\end{tabular}

No differences in ghrelin or obestatin levels or the ghrelin/obestatin ratio were observed between the allergy-positive group $(n=32)$ and the allergy-negative group ( $n=19)$ (Table 2). The mean ghrelin levels, obestatin levels, ghrelin/obestatin ratios, total IgE levels, and HOMA-IR scores in these groups were $2.11 \pm 1.76 \mathrm{ng} / \mathrm{mL}$ and $2.68 \pm 2.56 \mathrm{ng} / \mathrm{mL}, 6.08 \pm$ $5.23 \mathrm{ng} / \mathrm{mL}$ and $6.63 \pm 6.31 \mathrm{ng} / \mathrm{mL}, 0.41 \pm 1.74$ and $0.85 \pm 1.82,171.65 \pm 230.55 \mathrm{IU} / \mathrm{mL}$ and $281.51 \pm$ $502.26 \mathrm{IU} / \mathrm{mL}$, and $3.96 \pm 3.10$ and $2.93 \pm 1.65$, respectively (Table 4 ).

\section{Data by Sex}

Patients with asthma (37 females and 14 males) whose mean age, $\mathrm{BMI}$, and waist circumference were similar were compared in terms of their sex. Mean ACT score was $16.78 \pm 4.25$ in females and $18.43 \pm$ 3.40 in males $(p=0.20)$. The mean ghrelin levels, obestatin levels, and ghrelin/obestatin ratios in these groups were $2.17 \pm 2.22 \mathrm{ng} / \mathrm{mL}$ and $2.73 \pm 1.69 \mathrm{ng} /$ $\mathrm{mL}, 5.28 \pm 4.56 \mathrm{ng} / \mathrm{mL}$ and $8.94 \pm 7.25 \mathrm{ng} / \mathrm{mL}$, and $0.43 \pm 1.96$ and $0.94 \pm 2.13$, respectively.

\section{HOMA-IR Status}

No association was found between the HOMA-IR index and the ACT score $(r=-0.136, p=0.34)$, nor between the ACT score and the full control, partial control, and non-control groups $(p=0.42)$. A significant correlation was detected between ghrelin level and the HOMA-IR index $(r=-0.236, p=0.027)$. A negative correlation was observed between the obestatin level and the HOMA-IR index $(r=-0.229, p=$ 0.033). No association was found between the ghrelin/obestatin ratio and the HOMA-IR index $(r=$ 0.033, $\mathrm{p}=0.76$ ).

\section{DISCUSSION}

Asthma is a chronic airway inflammatory disorder which consists of chronic inflammation; associated with airway hyper-responsiveness and airflow obstructions that lead to recurrent wheezing episodes, dyspnea, chest tightness, and coughing (11).

Inhaled steroids may inhibit body growth (12). In addition, a low birth weight may also be a risk factor for asthma and patients with allergies. Indeed, in our study, asthma patients were significantly shorter than controls, and those with allergic asthma were shorter than those with non-allergic asthma.

Several studies have investigated the relationship between asthma and obesity hormones, such as leptin, adiponectin, and ghrelin. Unfortunately, no study has investigated the relationship between asthma and serum levels of obestatin, until now. We investigated the association between asthma and ghrelin and obestatin levels, independent of obesity status. We also compared the results of skin prick tests between patients with asthma and controls. Significant differences in ghrelin and obestatin levels and the ghrelin/obestatin ratio were observed between patients with stable asthma and healthy controls, which had similar sex ratio distributions, mean BMIs, and waist circumferences.

Ghrelin is an appetite stimulator in humans (13). However, there is little information on ghrelin levels in patients with asthma. In our study, ghrelin levels were not different between non-obese patients with asthma and control subjects. The mechanism by which ghrelin decreases in obese subjects has not been elucidated (14). Tsaroucha et al. reported that ghrelin concentrations are significantly lower in 
patients with asthma compared to healthy controls (15). In Matsumoto et al., ghrelin levels tended to be lower in patients with asthma than in non-asthmatic subjects but the differences were not statistically significant, as in our study (16). Yuksel et al. reported that ghrelin levels decrease in children with asthma and suggested that ghrelin has an anti-inflammatory role in the pathogenesis of asthma (17).

Ghrelin is a hormone released from stomach that increases appetite and decreases fat utilization. It regulates the short and long term energy consumption balance $(18,19)$. Dieting changes ghrelin levels as a response and affects bodyweight (20). Obese individuals have lower blood ghrelin levels compared to thinner people (14). Weight loss resulting from reduced calorie intake increases the circulating levels of ghrelin (21). Due to the strict relationship between ghrelin and obesity, we tested the independent effects of obesity on ghrelin levels in our study. The results of a previous study indicated that ghrelin levels are lower in obese subjects than in healthy controls (22).

Obestatin suppresses feeding drive, inhibits jejunal contractions, and decreases weight gain (6). It is a novel peptide shares coomon origins with ghrelin and is thought to function close to that of ghrelin. However, after the first report describing putative opposite effects of obestatin and ghrelin, several studies have not been able to confirm this hypothesis $(6,23-25)$. No study has investigated the relationship between obestatin and asthma, but a few studies have identified a relationship between obestatin levels and chronic obstructive pulmonary disease (COPD) and obstructive sleep apnea syndrome (OSAS). Lei et al. found a significant increase in obestatin levels in 32 patients with COPD and a $\mathrm{BMI}<20$ $\mathrm{kg} / \mathrm{m}^{2}$ and 22 healthy controls with a normal BMI. A positive correlation was detected between obestatin and CRP levels (26). Zirlik et al. reported that obestatin levels were lower in an OSAS group than in a control group. However, no significant relationship was detected between obestatin levels in patients with OSAS undergoing continuous positive airway pressure treatment and controls. In addition, an association has been established between obestatin levels and BMI and the HOMA index (27). Liu et al. reported lower levels of ghrelin and obestatin in 95 obese patients with OSAS compared to 30 non-obese patients with OSAS and 30 normal controls. No relationship has been established between OSAS and ghrelin/obestatin levels independent of obesity (28).
Kasayama et al. reported significantly higher CRP levels in 329 patients with stable asthma compared to 1684 healthy volunteers; levels were also higher in patients who used inhaled steroids (29). Pellizzaro et al. reported that the patients with asthma had significantly higher CRP levels compared to the healthy controls (30). Another study reported that, despite elevated high-sensitivity (hs)-CRP levels in patients with asthma compared to controls, there was no relationship between ACT results and hs-CRP level (31). In our study, asthma group had significathly higher CRP levels than the control group, but CRP levels and ACT results were not correlated. This supports the notion that the relationship between asthma symptoms and inflammation severity is not always directly proportional.

We found no association between obestatin levels and the ghrelin/obestatin ratio between patients with asthma and controls. No study has found an association between obestatin level and the HOMA index.

In a previous study, we observed higher HOMA-IR scores in an asthma group than in controls with an average BMI (32). HOMA-IR height and insulin resistance may indicate chronic inflammation in these patients. High HOMA-IR scores may also be associated with bronchial hyper-reactivity and asthma in obese children $(33,34)$. In another study, despite the fact that IR was higher in allergic patients with asthma than in controls, there was no difference in non-allergic patients with asthma (35).

In our study, increased IR was detected in both allergic and non-allergic patients with asthma compared to controls, independent of $\mathrm{BMI}$ and waist circumference. No differences in HOMA-IR scores were detected between allergic and non-allergic patients with asthma. However, there may be an association between systemic inflammation and asthma or use of an inhaled steroid and IR because of the relationship between bronchial hyper-reactivity, the inflammatory response, and IR. Future research should consider the pathophysiology of IR in patients with asthma. We did not find a relationship between asthma, HOMAIR scores, and control of asthma, suggesting that asthma symptoms and severity of inflammation are not always parallel.

We also found that IgE levels are not associated with ghrelin in non-obese patients with asthma compared to controls. However, in a recent study it is shown that in obese children, blood IgE levels and ghrelin 
are inversely correlated, thus authors extrapolated that ghrelin inhibits IgE synthesis (4). Children were divided in two new groups and serum levels of leptin and ghrelin were compared according to the results of skin prick tests by Çobanoğlu et al. There was no statistically significant difference between the two groups (36).

The main limitation of our study is that the sample size was relatively small. Furthermore, there are many variants of asthma, such as atopic, a cough variant, and aspirin-induced asthma. A study based on each type of asthma with a larger number of subjects is needed to show which type of asthma is associated with obestatin and ghrelin levels.

Our findings suggest that there was not significant difference between non obese asthma patients and control patients group according to serum ghrelin, obestatin and ghrelin/obestatin ratio. These hormones were not associated with allergy status. We found lower ghrelin levels in obese subjects but no differences in obestatin levels, similar to previous studies. To illuminate this subject, more studies with larger samples and groups divided by detailed criterias of asthma subtypes are needed.

\section{CONFLICT of INTEREST}

There is no conflict of interest related to this study.

\section{AUTHORSHIP CONTRIBUTIONS}

Concept/Design: DK, BB

Analysis/Interpretation: DK, BB

Data Acquisition: DK, BB

Writting: DK, HK

Critical Revision: DK, HK

Final Approval: DK, HK

\section{REFERENCES}

1. Gunnbjornsdottir MI, Omenaas E, Gislason T, et al. Obesity and nocturnal gastro-oesophageal reflux are related to onset of asthma and respiratory symptoms. Eur Respir J 2004;24(1):116-21.

2. Beuther DA, Sutherland ER. Overweight, obesity, and incident asthma: a meta-analysis of prospective epidemiologic studies. Am J Respir Crit Care Med 2007; 175(7):661-6.

3. Rasmussen F, Hancox RJ. Mechanisms of obesity in asthma. Curr Opin Allerg Clin Immunol 2014;14(1):35-43.

4. Matsuda K, Nishi Y, Okamatsu Y, Kojima M, Matsuishi T. Ghrelin and leptin: a link between obesity and allergy? I Allerg Clin Immunol 2006;117(3):705-6.
5. Cummings DE, Purnell JQ, Frayo RS, Schmidova K, Wisse $B E$, Weigle DS. A preprandial rise in plasma ghrelin levels suggests a role in meal initiation in humans. Diabetes 2001;50(8):1714-9.

6. Zhang IV, Ren PG, Avsian-Kretchmer O, et al. Obestatin, a peptide encoded by the ghrelin gene, opposes ghrelin's effects on food intake. Science 2005;310(5750):996-9.

7. Suzuki K, Jayasena CN, Bloom SR. Obesity and appetite control. Experimen Diabetes Res 2012;2012:824305.

8. Aygen B, Dogukan A, Dursun FE, et al. Ghrelin and obestatin levels in end-stage renal disease. I Intern Med Res 2009;37(3):757-65.

9. Xin X, Ren AJ, Zheng $X$, et al. Disturbance of circulating ghrelin and obestatin in chronic heart failure patients especially in those with cachexia. Peptides 2009;30(12):2281-5.

10. Takemura M, Matsumoto H, Niimi A, et al. High sensitivity C-reactive protein in asthma. Eur Respir J 2006;27(5):90812.

11. Warrington R. Immunotherapy in asthma. Immunother 2010;2(5):711-25.

12. Zhang L, Prietsch SO, Ducharme FM. Inhaled corticosteroids in children with persistent asthma: effects on growth. Cochrane Rev J 2014;9(4):829-930.

13. Marzullo P, Verti B, Savia G, et al. The relationship between active ghrelin levels and human obesity involves alterations in resting energy expenditure. J Clin Endocrinol Metabolism 2004;89(2):936-9.

14. Tschop M, Weyer C, Tataranni PA, Devanarayan V, Ravussin E, Heiman ML. Circulating ghrelin levels are decreased in human obesity. Diabetes 2001;50(4):707-9.

15. Tsaroucha A, Daniil Z, Malli F, et al. Leptin, adiponectin, and ghrelin levels in female patients with asthma during stable and exacerbation periods. J Asthma 2013;50(2):188-97.

16. Matsumoto $Y$, Toyomasu K, Uchimura N, Ishitake T. Lowmolecular-weight adiponectin is more closely associated with episodes of asthma than high-molecular-weight adiponectin. Endoc J 2013;60(1):119-25.

17. Yuksel H, Sogut A, Yilmaz O, Onur E, Dinc G. Role of adipokines and hormones of obesity in childhood asthma. Allerg Asthma Immunol Res 2012;4(2):98-103.

18. Meier U, Gressner AM. Endocrine regulation of energy metabolism: review of pathobiochemical and clinical chemical aspects of leptin, ghrelin, adiponectin, and resistin. Clin Chem 2004;50(9):1511-25.

19. Tschop M, Smiley DL, Heiman ML. Ghrelin induces adiposity in rodents. Nature 2000;407(6806):908-13.

20. Otto B, Cuntz U, Fruehauf E, et al. Weight gain decreases elevated plasma ghrelin concentrations of patients with anorexia nervosa. Eur J Endocrin 2001;145(5):669-73.

21. Zahorska-Markiewicz B, Mizia-Stec K, OlszaneckaGlinianowicz M, Janowska J. Effect of weight reduction on serum ghrelin and TNFalpha concentrations in obese women. Eur J Intern Med 2004; 15(3):172-5. 
22. Ozkan Y, Aydin S, Donder E, et al. Effect of orlistat on the total ghrelin and leptin levels in obese patients. I Physiol Biochem 2009;65(3):215-23.

23. Chartrel N, Alvear-Perez R, Leprince J, et al. Comment on "Obestatin, a peptide encoded by the ghrelin gene, opposes ghrelin's effects on food intake". Science 2007;315(5813):766.

24. Nogueiras R, Pfluger P, Tovar $S$, et al. Effects of obestatin on energy balance and growth hormone secretion in rodents. Endocrinol 2007;148(1):21-6.

25. Zizzari P, Longchamps R, Epelbaum J, Bluet-Pajot MT. Obestatin partially affects ghrelin stimulation of food intake and growth hormone secretion in rodents. Endocrinol 2007; 148(4):1648-53.

26. Lei $Y$, Liang $Y$, Chen Y, Liu X, Liao X, Luo F. Increased circulating obestatin in patients with chronic obstructive pulmonary disease. Multidisciplinary Respir Med 2014;9(1):1.

27. Zirlik S, Hauck T, Fuchs FS, Neurath MF, Konturek PC, Harsch IA. Leptin, obestatin and apelin levels in patients with obstructive sleep apnoea syndrome. Medical Science Monitor 2011;17(3):CR159-CR164.

28. Liu W, Yue H, Zhang J, Pu J, Yu Q. Effects of plasma ghrelin, obestatin, and ghrelin/obestatin ratio on blood pressure circadian rhythms in patients with obstructive sleep apnea syndrome. Chinese Med J 2013;127(5):850-5.
29. Kasayama S, Tanemura M, Koga M, Fujita K, Yamamoto $H$, Miyatake A. Asthma is an independent risk for elevation of plasma C-reactive protein levels. Clinica Chimica Acta 2009;399(1):79-82.

30. Pellizzaro AM, Heuertz RM. C-reactive protein levels are elevated in asthma and asthma-like conditions. Clin Lab Sc $2010 ; 23(4): 223$.

31. Sigari N, Ghasri H. Correlation between hs-CRP and asthma control indices. Tanaffos 2013;12(3):44.

32. Gulcan E, Bulut I, Toker A, Gulcan A. Evaluation of glucose tolerance status in patients with asthma bronchiale. I Asthma 2009;46(2):207-9.

33. Kim KM, Kim SS, Lee SH, et al. Association of insulin resistance with bronchial hyperreactivity. Asia Pacific Allergy 2014;4(2):99.

34. Sánchez Jiménez J, Herrero Espinet FJ, Mengibar Garrido JM, et al. Asthma and insulin resistance in obese children and adolescents. Pediatr Allerg Immunol 2014;25(7):699-705.

35. Husemoen L, Glümer C, Lau C, Pisinger C, Morch L, Linneberg A. Association of obesity and insulin resistance with asthma and aeroallergen sensitization. Allergy 2008;63(5):575-82.

36. Cobanog/u N, Galip N, Dalkan C, Bahceciler NN. Leptin, ghrelin and calprotectin: inflammatory markers in childhood asthma? Multidisciplinary Respir Med 2013;8(1):1. 